\title{
New Palladium (II) Complexes Bearing Benzopyran Derivative Ligands: Synthesis and Characterization
}

\author{
A.M. Mostafa, A.I. Hanafy, Naglaa M. Abd El-Rahman* \\ and M.M. El-Sayed \\ Department of Chemistry, Faculty of Science, Al-Azhar University \\ and *Department of Green Chemistry, National Research Center, \\ Cairo, Egypt.
}

\begin{abstract}
D ALLADIUM complexes of (4-methoxyphenyl benzopyran, 4- fluorophenyl benzopyran and 4-(2-chloro-5-nitro) phenyl benzopyran ligands) have been synthesized and characterized using different tools such as IR, UV/Vis, ${ }^{1} \mathrm{H}-\mathrm{NMR}$, elemental analysis, thermal analysis, and mass spectroscopy. The mode of binding $\mathrm{Pd}$ (II) ion with the ligands shows that the Pd (II) ion binds with the ligands through the amino group nitrogen atom and cyanide group nitrogen atom of the ligands which revealed a square-planar coordination geometry at the metal center $\left[\mathrm{Pd} \mathrm{L} \mathrm{L}_{1} .2 \mathrm{Cl}\right] 0.5 \mathrm{H}_{2} \mathrm{O},[\mathrm{Pd} \mathrm{L} 2.2 \mathrm{Cl}] 1.5 \mathrm{H}_{2} \mathrm{O}$ and $\left[\mathrm{Pd} \mathrm{L}_{3} .2 \mathrm{Cl}\right]$.
\end{abstract}

Keywords: Palladium, Benzopyran and Microwave .

Bidentate chelating ligands are often used to fix the active coordination sites of Pd (II) complexe in a cis-arrangement ${ }^{(1)}$. The significant similarity between the coordination chemistry of palladium (II) and platinum (II) compounds has advocated studies of Pd (II) complexes as antitumor drugs. A key factor that might explain why platinum is most useful comes from the ligand-exchange kinetics. The hydrolysis in palladium complexes is too rapid: 105 times faster than for those of corresponding platinum analogues ${ }^{(2)}$. They dissociate readily in solution leading to very reactive species that are unable to reach their pharmacological targets. Compared to cisplatin, the corresponding cispalladium, cis- $\left[\mathrm{PdCl}_{2}\right.$ $(\mathrm{NH} 3)_{2}$ ] does not show antitumoral activity. It is well known that it undergoes an inactive trans-conformation and that the two compounds hydrolyze very fast assuming that they interact in vivo with a lot of molecules particularly proteins preventing them to reach the DNA, their pharmalogical target ${ }^{(3)}$. The considerably higher activity of palladium complexes implies that if an antitumor palladium drug is to be developed, it must somehow be stabilized by a chelate or a strongly coordinated, bulky monodentate nitrogen ligand and a suitable leaving group ${ }^{(4,5)}$.

Due to the steric effect that results from the bulk on the donor atoms, these ligands could minimize any possible cis-trans isomerism and insure the direct separation of the desired trans-Pd isomers ${ }^{(6)}$. In general, research results indicated that most of the trans-palladium complexes showed a better activity than the cisplatinum isomers and superior activity than that of the cis-palladium isomers. More importantly, they showed activities equal to (or superior than) those of cisplatin, 
carboplatin, and oxaliplatin (the anticancer drugs in clinical use) in vitro ${ }^{(4)}$. Studies of platinum and palladium compounds with biologically active carriers have yielded promising results in the field of anticancer chemistry and there is potential for varying the biological activity of these complexes by changing the structure of the carrier ${ }^{(7)}$. Significant advances have emerged from this methodology of design ${ }^{(2,4)}$.

The use of microwave radiation to enhance organic reactions in environmentally benign solvents such as water, which is inexpensive and not dangerous, represents very powerful green chemical technology both from economic and synthetic points of view. This not only reduces the burden of organic solvent disposal but also enhances the rate of the reaction. In recent years, the synthesis of compounds having benzopyran rings has attracted great interest, because they have diverse pharmacological activities ${ }^{(8)}$. In addition, a large number of benzopyran derivatives possess potent relaxant activity on blood vessels, cardiac muscle, and other smooth muscles ${ }^{(9,10)}$. We have prepared a new palladium (II) complexes containing benzopyran moiety.

Materials and methods

\section{Experimental}

benzylaldehyde and its substituted derivatives, were purchased from Aldrich Chemical Co. Dimedone was purchased from Across Organics Co. (Belgium), malononitrile was obtained from Merck Co., Germany. Hydrochloric acid, potassium hydroxide, potassium fluoride, sodium acetate trihydrate, basic alumina, anhydrous sodium sulphate and sodium nitrite were purchased from ElNasr Pharmaceutical Co. Kojic acid and palladium chloride were purchased from Merck company.

Synthesis of-(4-methoxyphenyl benzopyran $\left(L_{1}\right)$,4-fluorophenyl benzopyran $\left(L_{2}\right)$ and 4(2-chloro-5-nitro) phenyl benzopyran $\left.\left(L_{3}\right)\right)$ ligands

A mixture of aromatic aldehyde $1(5 \mathrm{mmol})$ and malononitrile $2(0.33 \mathrm{~g}$, $5 \mathrm{mmol})$ were mixed together in water $(2 \mathrm{ml})$ in a tightly closed tube, and subjected to microwave irradiation for the appropriate time until completion of the reaction for $\left(\mathrm{L}_{1}, 4 \mathrm{~min}, \mathrm{~L}_{2}, 2 \mathrm{~min}\right.$ and $\mathrm{L}_{3}, 1 \mathrm{~min}$ ) (monitored by TLC). The precipitate formed was filtered, washed with water to give the pure product 3 with sharp melting point (Scheme 1).

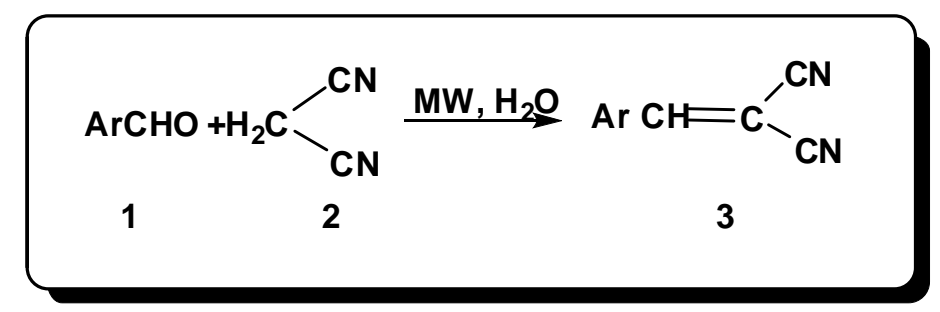

Scheme 1.

An equimolar amount of arylidene malononitrile $3(5 \mathrm{mmol})$ and dimedone 4 $(0.7 \mathrm{~g}, 5 \mathrm{mmol})$ were mixed together in water $(2 \mathrm{ml})$ in a tightly closed tube, and

Egypt. J. Chem. 55, No. 1 (2012) 
subjected to microwave irradiation for the appropriate time until completion of the reaction $\left(\mathrm{L}_{1}, 4 \mathrm{~min}, \mathrm{~L}_{2}, 2 \mathrm{~min}\right.$ and $\mathrm{L}_{3}, 3 \mathrm{~min}$ ) (monitored by TLC). The precipitate formed filtered and washed with water gave pure product 5 (Scheme 2).

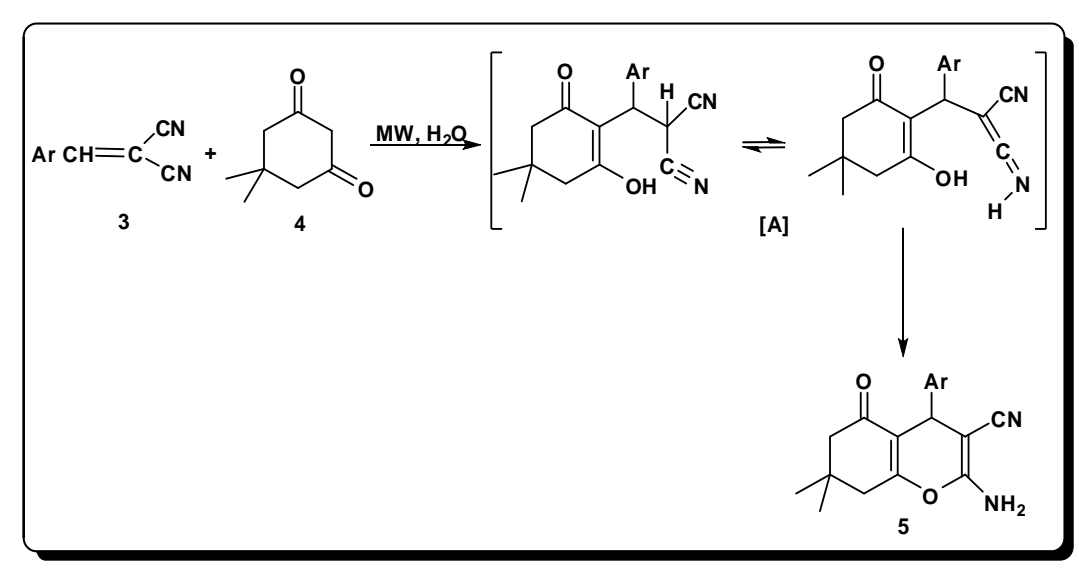

Scheme 2.

Synthesis of Pd (II) complex

Palladium (II) chloride 2-3 gm (0.1 moles) was dissolved in $\sim 40 \mathrm{ml}$ absolute ethanol, and then added to 0.1 mole of the prepared ligands $\left(\mathrm{L}_{1}, \mathrm{~L}_{2}\right.$ and $\left.\mathrm{L}_{3}\right)$ dissolved in $\sim 40 \mathrm{ml}$ absolute ethanol. The mixture was heated under reflux for two hr; the bluish precipitate formed were filtered off and finally washed by hot ethanol several times.

\section{Physical methods}

Carbon, hydrogen and nitrogen contents were determined at the Microanalytical Unit, Cairo University, Egypt. IR spectra of the ligand and its solid complexes were measured in $\mathrm{KBr}$ on a Mattson 5000 FTIR spectrometer at National Research Centre, Dokki, Cairo, Egypt.

All electronic spectra and kinetic measurement were performed using Varian Cary 4 Bio UV/vis spectrophotometer at National Research Centre, Dokki, Cairo, Egypt. Thermal analysis measurements (TGA, DTA) were recorded on a Shimadzu thermo-gravimetric analyzer model TGA-50H, using $20 \mathrm{mg}$ samples. The flow rate of nitrogen gas and heating rate were $20 \mathrm{~cm}^{3} \mathrm{~min}^{-1}$ at $10^{\circ} \mathrm{C} \mathrm{min}^{-1}$, respectively. Mass spectra were recorded at Al-Azhar University, Egypt. 


\section{Results and Discussion}

Characterization of the ligands $\left(L_{1}, L_{2}\right.$, and $\left.L_{3}\right)$

Characterization of $L .^{(11)}$

The infrared spectrum of the 4-methoxyphenyl benzopyran $L_{1}$ shows weak bands at 3000 and $2839 \mathrm{~cm}^{-1}$, which were assigned to the aromatic and aliphatic $\mathrm{C}-\mathrm{H}$ stretches, respectively. A strong band observed at $2192 \mathrm{~cm}^{-1}$ is likely to be due to $v \mathrm{C} \equiv \mathrm{N}$ stretches ${ }^{(12,13)}$. Band at $3372 \mathrm{~cm}^{-1}$ was assigned to $v \mathrm{NH}_{2}$. The ligand showed band at 1653 was assigned to $v \mathrm{C}=\mathrm{O}^{(14)}$.

The ${ }^{1} \mathrm{H}-\mathrm{NMR}$ spectrum revealed peaks which were attributed to $\delta=1.03$ (s, $\left.3 \mathrm{H}, \mathrm{CH}_{3}\right), 1.19\left(\mathrm{~s}, 3 \mathrm{H}, \mathrm{CH}_{3}\right), 2.23\left(\mathrm{~d}, 1 \mathrm{H}, J_{\mathrm{AB}}=16 \mathrm{~Hz}, \mathrm{H}-8 \mathrm{a}\right), 2.31\left(\mathrm{~d}, 1 \mathrm{H}, J_{\mathrm{AB}}=\right.$ $16 \mathrm{~Hz}, \mathrm{H}-8 \mathrm{~b}), 2.45\left(\mathrm{~s}, 2 \mathrm{H}, \mathrm{C}_{6}-\mathrm{H}\right), 3.79\left(\mathrm{~s}, 3 \mathrm{H}, \mathrm{OCH}_{3}\right), 4.02\left(\mathrm{~s}, 1 \mathrm{H}, \mathrm{C}_{4}-\mathrm{H}\right)$, 4.95(s, 2H, $\mathrm{NH}_{2}, \mathrm{D}_{2} \mathrm{O}$ exchangeable), 7.11-7.29 (m, 4H, Ar-H).

All these data together with the molecular weight from the mass spectrum $(\mathrm{m} / \mathrm{z}=324)$ and elemental analysis proposed the structure of the ligand as shown in structure (1).

$$
\mathbf{A r}=
$$<smiles>Cc1ccc(F)cc1</smiles><smiles>O=[N+]([O-])c1ccc(Cl)c(C[Al])c1</smiles><smiles>COc1ccc([Al]#[W])cc1</smiles><smiles>COc1ccc(C2C(C#N)=C(N)OC3=C2C(=O)CC(C)(C)C3)cc1</smiles>

2-Amino-4-(4-methoxyphenyl)-5, 6, 7, 8-tetrahydro-7, 7-dimethyl-5-oxo-4H-chromene-3carbonitrile

\section{Structure (1) $\left(\mathbf{L}_{1}\right)$}

Characterization of $L_{2}{ }^{(15)}$

The IR spectrum of the (4-fluorophenyl) benzopyran $\left(\mathrm{L}_{2}\right)$ shows band at 3356 $\mathrm{cm}^{-1}$ was assigned to $v \mathrm{NH}_{2}$. The ligand showed bands at 1650 and $2190 \mathrm{~cm}^{-1}$ were assigned to $\vee \mathrm{C}=\mathrm{O}, \vee \mathrm{C} \equiv \mathrm{N}$.

Egypt. J. Chem. 55, No. 1 (2012) 
${ }^{1} \mathrm{H}$ NMR $\left(\mathrm{CDCL}_{3}\right): \delta=1.05\left(\mathrm{~s}, 3 \mathrm{H}, \mathrm{CH}_{3}\right), 1.083\left(\mathrm{~s}, 3 \mathrm{H}, \mathrm{CH}_{3}\right), 1.67(\mathrm{~d}, 1 \mathrm{H}$, $\left.J_{\mathrm{AB}}=16 \mathrm{~Hz}, \mathrm{H}-8 \mathrm{a}\right), 2.23\left(\mathrm{~d}, 1 \mathrm{H}, J_{\mathrm{AB}}=16 \mathrm{~Hz}, \mathrm{H}-8 \mathrm{~b}\right), 2.44\left(\mathrm{~s}, 2 \mathrm{H}, \mathrm{C}_{6}-\mathrm{H}\right), 4.33(\mathrm{~s}$, $\left.1 \mathrm{H}, \mathrm{C}_{4}-\mathrm{H}\right), 5.91\left(\mathrm{~s}, 2 \mathrm{H}, \mathrm{NH}_{2}, \mathrm{D}_{2} \mathrm{O}\right.$ exchangeable), 6.79-7.23 (m, 4H, Ar-H).

All these data together with the molecular weight determined from the mass spectrum $(\mathrm{m} / \mathrm{z}=312)$ and elemental analysis proposed the structure of the ligand as shown in structure (2).<smiles>CC1(C)CC(=O)C2=C(C1)OC(N)=C(C#N)C2c1ccc(F)cc1</smiles>

2-Amino-4-(4-fluorophenyl)-5,6,7,8-tetrahydro-7,7-dimethyl-5-oxo-4H-chromene -3-carbonitrile

Structure (2) $\left(\mathbf{L}_{2}\right)$

\section{Characterization of $L_{3}$}

The IR spectrum of the (2-chloro-5-nitrophenyl) benzopyran $\left(\mathrm{L}_{3}\right)$ shows bands at $3447,3332 \mathrm{~cm}^{-1}$ assigned to $\mathrm{vNH}_{2}$. The ligand also showed bands at $1664,2186 \mathrm{~cm}^{-1}$ assigned to $v \mathrm{C}=\mathrm{O}, v \mathrm{C} \equiv \mathrm{N}$.

The ${ }^{1} \mathrm{H}-\mathrm{NMR}$ spectrum revealed peaks which were attributed to $\delta=1.09$ (s, $\left.3 \mathrm{H}, \mathrm{CH}_{3}\right), 1.13\left(\mathrm{~s}, 3 \mathrm{H}, \mathrm{CH}_{3}\right), 2.17-2.29\left(\mathrm{~m}, 2 \mathrm{H}, \mathrm{C}_{8}-\mathrm{H}\right), 2.48-2.55\left(\mathrm{~m}, 2 \mathrm{H}, \mathrm{C}_{6}-\mathrm{H}\right)$, $4.01\left(\mathrm{~s}, 1 \mathrm{H}, \mathrm{C}_{4}-\mathrm{H}\right), 5.55\left(\mathrm{~s}, 2 \mathrm{H}, \mathrm{NH}_{2}, \mathrm{D}_{2} \mathrm{O}\right.$ exchangeable $), 7.23-7.39(\mathrm{~m}, 3 \mathrm{H}$, Ar$\mathrm{H})$.<smiles>CC1(C)CC(=O)C2=C(C1)OC(N)=C(C#N)C2c1cc([N+](=O)[O-])ccc1Cl</smiles>

2-Amino-4-(2-chloro-5-nitrophenyl)-5,6,7,8-tetrahydro-7,7-dimethyl-5-oxo$4 H$-chromene-3-carbonitrile

Structure (3) ( $\left.\mathbf{L}_{3}\right)$ 
All these data together with the molecular weight determined from the mass spectroscopy $(\mathrm{m} / \mathrm{z}=373)$ and elemental analysis proposed the structure of the ligand as shown in structure (3).

Characterization of palladium complexes (Characterization of [Pd $\left.L_{1} .2 \mathrm{Cl}\right]$ $0.5 \mathrm{H}_{2} \mathrm{O},\left[\mathrm{Pd} \mathrm{L}_{2} .2 \mathrm{Cl}\right] 1.5 \mathrm{H}_{2} \mathrm{O}$ and $\left[\mathrm{PdL}_{3} .2 \mathrm{Cl}\right]$ complexes)

IR spectra of $P d($ II) complexes

The IR spectra of these complexes in $\mathrm{KBr}$ discs show that all the ligands behave as a bidentate coordinating to metal ions through the nitrogen atoms of $\mathrm{NH}_{2}$ and $\mathrm{C} \equiv \mathrm{N}$ forming stable five membered ring around the metal ion. By comparing the IR spectrum of the ligands with their complexes shown in Fig. 1-3, one can suggest the following: by disappearance of the band of cyano group there is a weak band in the curve which may be due to the cyano group in the complexes spectra; at the same time appearance of broad band completes the sentence. The coordination of $\mathrm{NH}_{2}$ nitrogen atom is also consistent with the presence of band at (450-475) $\mathrm{cm}^{-1}$ due to $v \mathrm{M}-\mathrm{N}$. Indeed, the appearance of new bands in the IR spectra of metal complexes as shown in Table 1 assigned M-N in addition to $\mathrm{M}-\mathrm{Cl}$ indicates the formation of the chelates, where chlorides compensate the positive charge on the metal ions in $\mathrm{PdL}_{1}, \mathrm{PdL}_{2}$ and $\mathrm{PdL}_{3}{ }^{(16,17)}$ in the proposed structures.

\section{Electronic spectral data of palladium complexes}

The electronic spectra of all palladium complexes (Fig.4-6) show three $d$-d spin allowed transitions. These are corresponding to the transitions from the three lower lying "d" levels to the empty $d_{x^{2}-y^{2}}$ orbital. The ground state is ${ }^{1} \mathrm{~A}_{1 \mathrm{~g}}$ and exited states corresponding to the above transitions are ${ }^{1} \mathrm{~A}_{2 \mathrm{~g}},{ }^{1} \mathrm{~B}_{1 \mathrm{~g}}$ and ${ }^{1} \mathrm{E}_{\mathrm{g}}$ in order of increasing energy. Three $\mathrm{d}-\mathrm{d}$ bands are observed in the region $205-265 \mathrm{~nm}, 295-351 \mathrm{~nm}$ and $351-405 \mathrm{~nm}$. These bands are due to

${ }^{1} \mathrm{~A}_{1 \mathrm{~g}} \rightarrow{ }^{1} \mathrm{~A}_{2 \mathrm{~g}},{ }^{1} \mathrm{~A}_{1 \mathrm{~g}} \rightarrow{ }^{1} \mathrm{~B}_{1 \mathrm{~g}}$ and ${ }^{1} \mathrm{~A}_{1 \mathrm{~g}} \rightarrow{ }^{1} \mathrm{E}_{\mathrm{g}}$ transitions ${ }^{(18)}$, respectively.

The electronic spectra of these complexes as well as their diamagnetic behavior indicate the square planar geometrical structure of the palladium complexes.

\section{Mass spectra of palladium complexes}

The mass spectrum of the palladium complexes (Fig.7) shows a molecular ion peak at $\mathrm{m} / \mathrm{z}=513(3.43 \%)$ which is corresponding to the cyclopalladate moiety $\left(\mathrm{C}_{19} \mathrm{H}_{21} \mathrm{Cl}_{2} \mathrm{~N}_{2} \mathrm{O}_{3.5} \mathrm{Pd}\right)$ of [Pd. $\left.\mathrm{L}_{1} .2 \mathrm{Cl}\right] 0.5 \mathrm{H}_{2} \mathrm{O}$ complex and the base peak was found in the spectrum at $\mathrm{m} / \mathrm{z}=287$ corresponding to $\left(\mathrm{C}_{17} \mathrm{H}_{17} \mathrm{FNO}_{2}\right)$. 
TABLE 1. IR spectral data of ligands $\left(\mathrm{L}_{1}, \mathrm{~L}_{2}, \mathrm{~L}_{3}\right)$ and their complexes with Pd (II).

\begin{tabular}{|c|c|c|c|c|c|c|}
\hline Compd & $\mathbf{v}_{\mathbf{C H}}$ arom & $\mathbf{v}_{\mathbf{C H}}$-aliph & $\mathbf{v}_{\mathbf{C}=\mathbf{N}}$ & $\mathbf{v}_{\mathrm{CO}}$ & $\mathbf{V}_{\mathbf{N H 2}}$ & $\mathbf{v}_{\mathbf{M}-\mathbf{N}}$ \\
\hline $\mathrm{L}_{1}$ & 3008 & 2833 & 2192 & 1653 & 3373,3314 & \\
\hline $\mathrm{PdL}_{1}$ & 3064 & 2846 & & 1654 & 3423,3245 & 470 \\
\hline $\mathrm{L}_{2}$ & 3091 & 2875 & 2190 & 1650 & 3356,3258 & \\
\hline $\mathrm{PdL}_{2}$ & 3075 & 2835 & & 1658 & 3440,332 & 2472 \\
\hline $\mathrm{L}_{3}$ & 3091 & 2873 & 2190 & 1658 & 3447,3332 & \\
\hline $\mathrm{PdL}_{3}$ & 3082 & 2810 & & 1657 & 3439,3212 & 458 \\
\hline
\end{tabular}

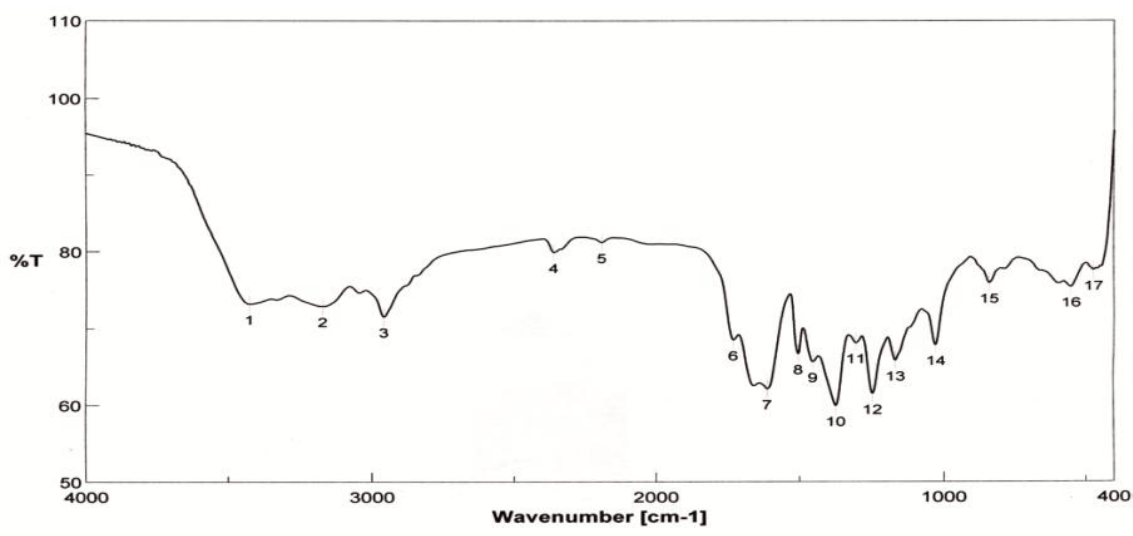

Fig 1. IR spectrum of $\left[\mathrm{PdL}_{1} .2 \mathrm{Cl}\right] 0.5 \mathrm{H}_{2} \mathrm{O}$ complex .

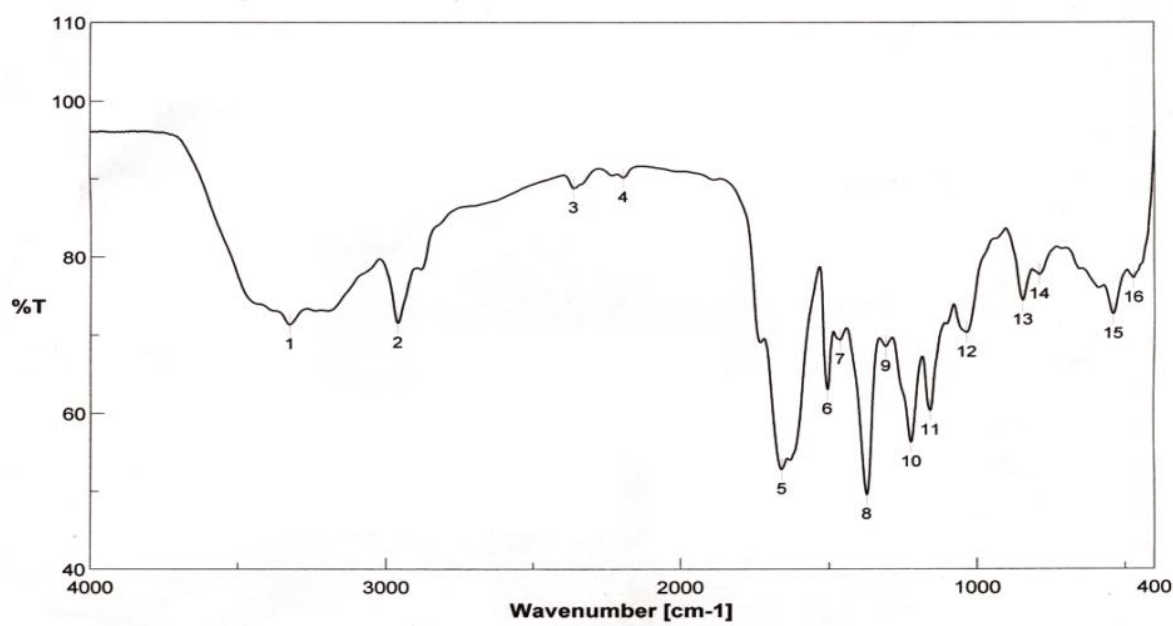

Fig. 2. IR spectrum of $\left[\mathrm{PdL}_{2} .2 \mathrm{CI}\right] 1.5 \mathrm{H}_{2} \mathrm{O}$ complex . 


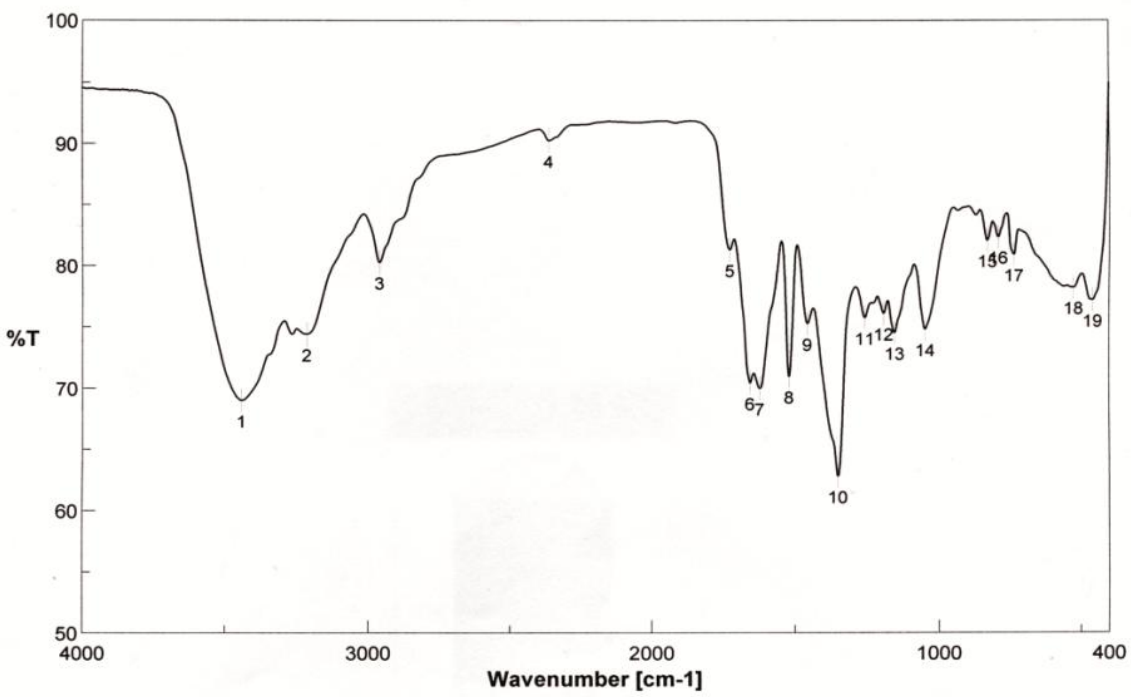

Fig. 3. IR spectrum of $\left[\mathrm{PdL}_{3} .2 \mathrm{Cl}\right]$ complex.

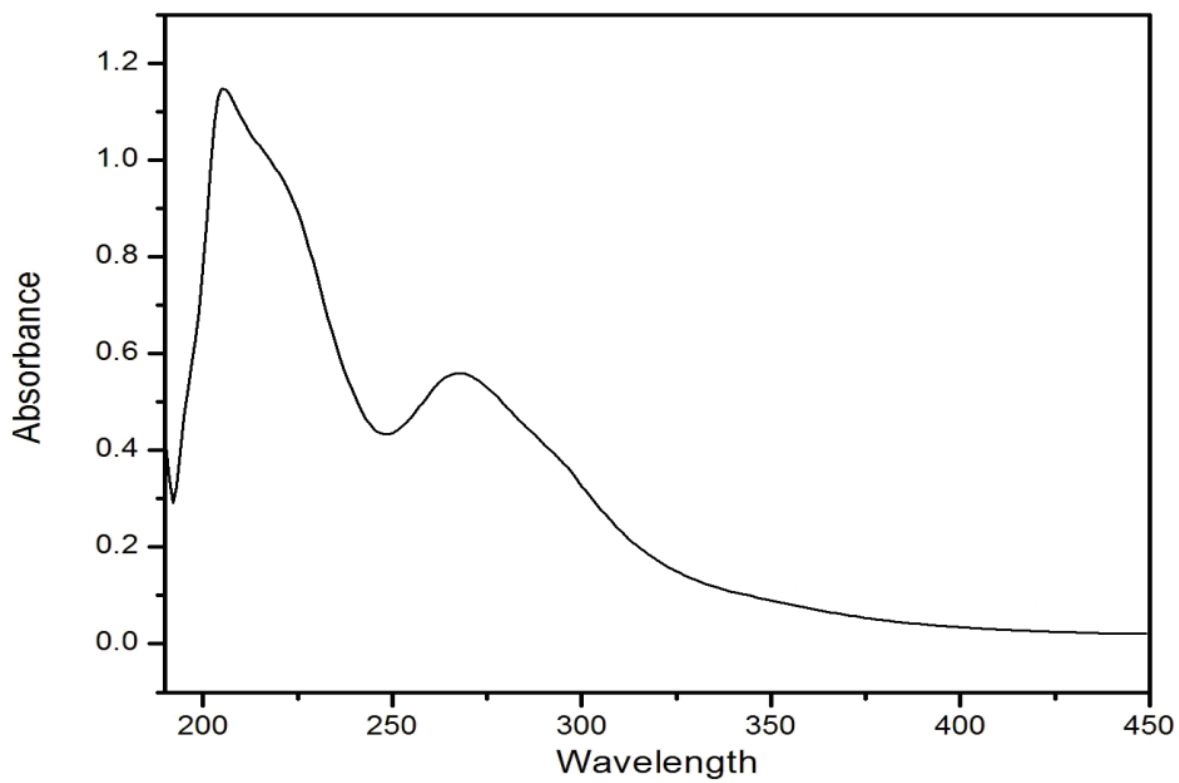

Fig. 4. Electronic spectra of $\left[\mathrm{PdL}_{1} .2 \mathrm{Cl}\right] 0.5 \mathrm{H}_{2} \mathrm{O}$ complex.

Egypt. J. Chem. 55, No. 1 (2012) 


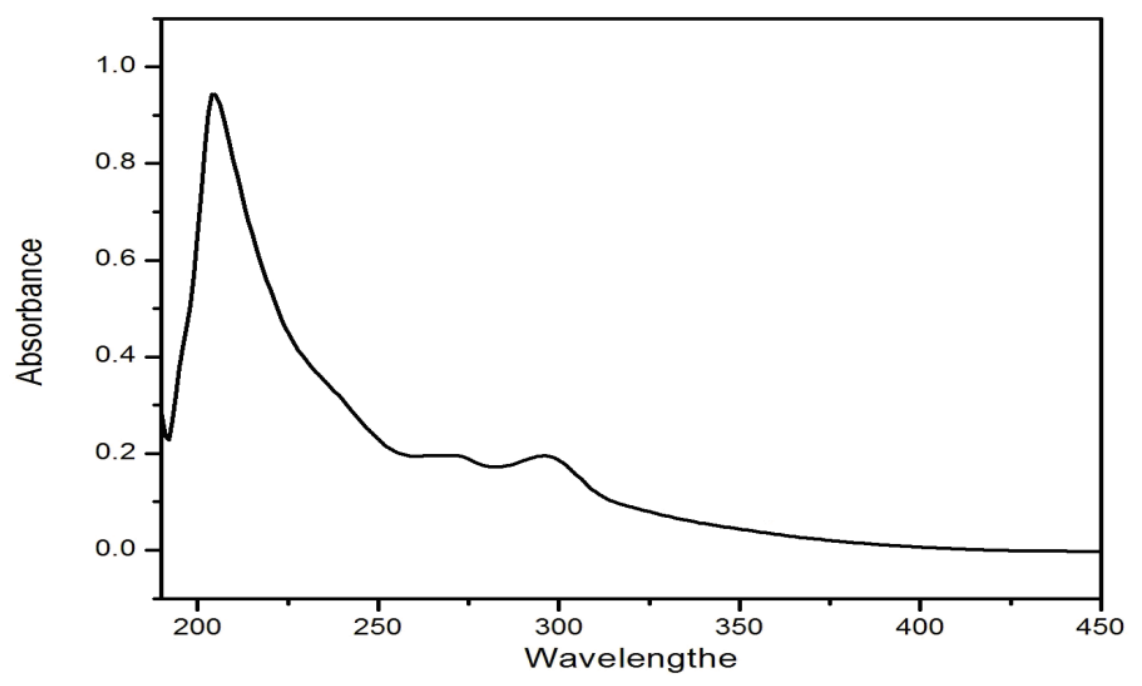

Fig. 5. Electronic spectra of $\left[\mathrm{PdL}_{2} \cdot 2 \mathrm{Cl}\right] 1.5 \mathrm{H}_{2} \mathrm{O}$ complex.

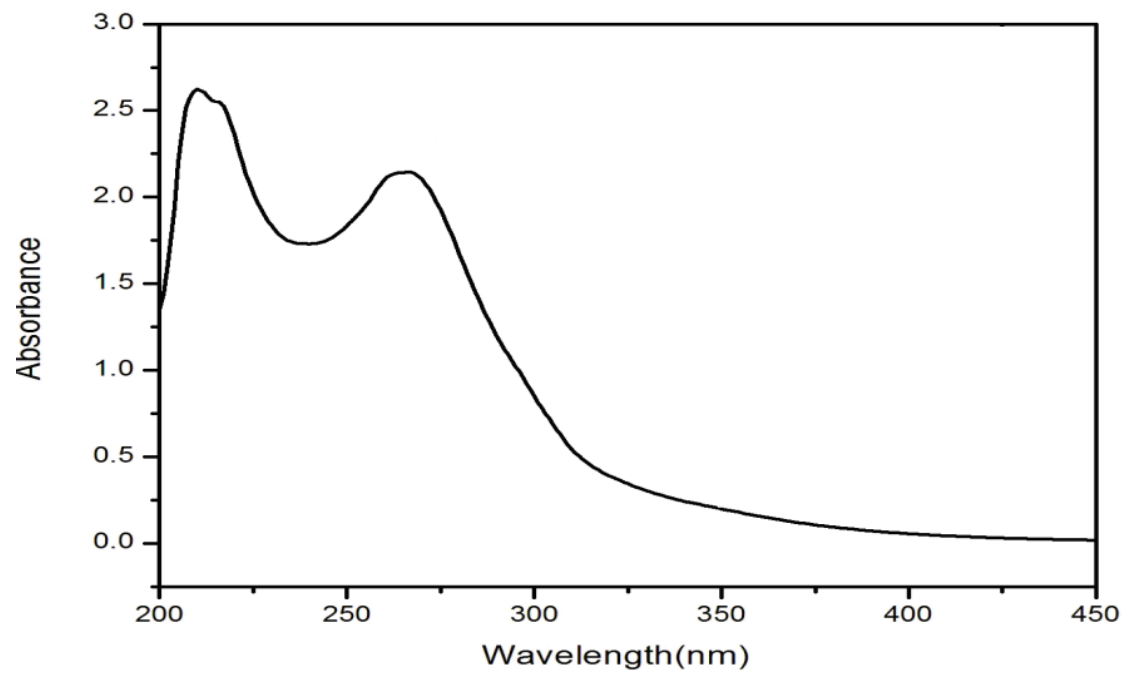

Fig. 6. Electronic spectra of $\left[\mathrm{PdL}_{3} .2 \mathrm{Cl}\right]$ complex .

The mass spectrum of palladium complex [Pd . $\left.\mathrm{L}_{2} .2 \mathrm{Cl}\right] 1.5 \mathrm{H}_{2} \mathrm{O}$ (Fig.8), shows a molecular ion peak at $\mathrm{m} / \mathrm{z}=517(2.21 \%)$ corresponding to the cyclopalladate moiety $\left(\mathrm{C}_{18} \mathrm{H}_{20} \mathrm{FCl}_{2} \mathrm{~N}_{2} \mathrm{O}_{3.5} \mathrm{Pd}\right)$. The base peak was found in the spectrum at $\mathrm{m} / \mathrm{z}=$ 210 corresponding to the $\left(\mathrm{C}_{14} \mathrm{H}_{12} \mathrm{NO}\right)$. 


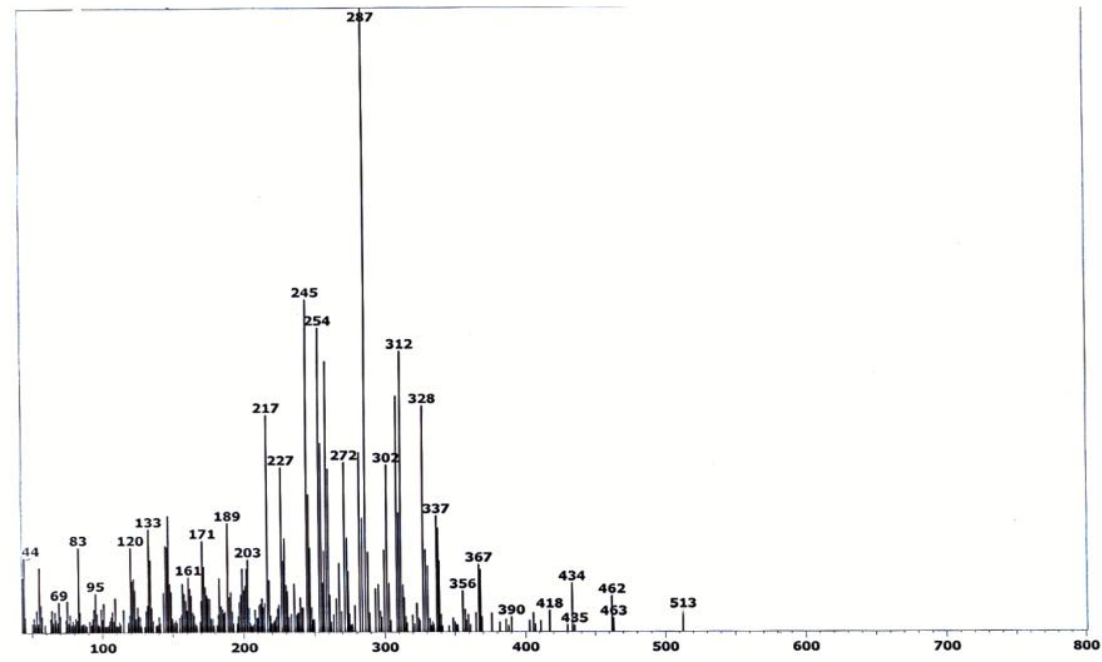

Fig. 7. Mass spectrum of $\left[\mathrm{PdL}_{1} 2 \mathrm{Cl}\right] \mathrm{0.5H}_{2} \mathrm{O}$ complex.

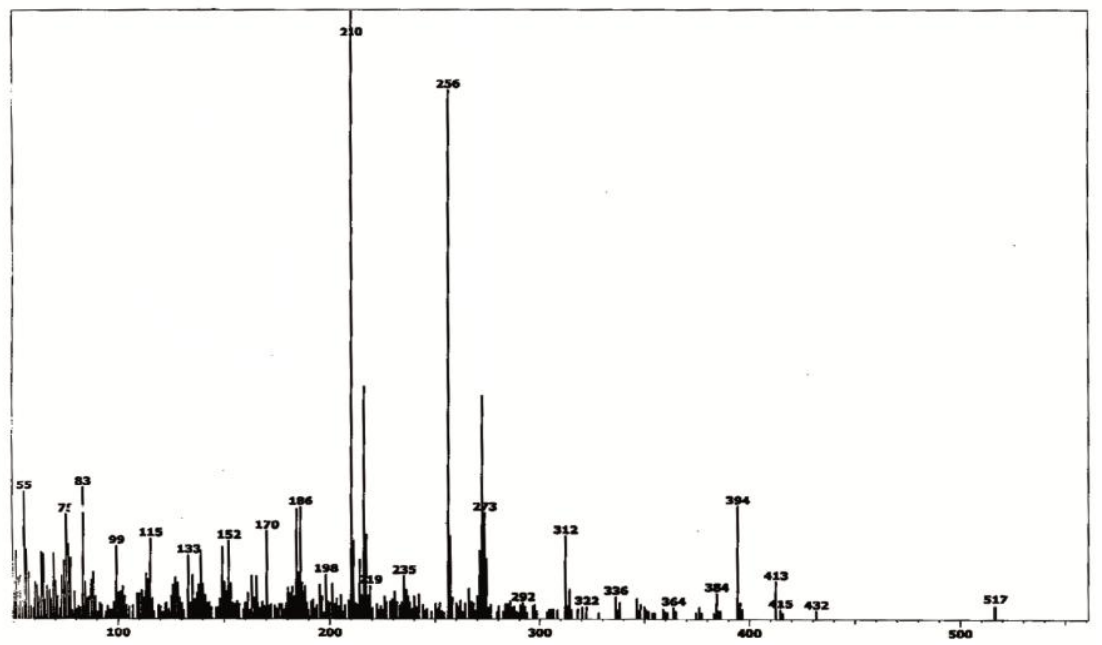

Fig. 8. Mass spectrum of $\left[\mathrm{Pd} \mathrm{L}_{2} .2 \mathrm{Cl}\right] 1.5 \mathrm{H} 2 \mathrm{O}$ complex.

The mass spectrum of palladium complex [Pd .. L $_{3} .2 \mathrm{Cl}$ ] (Fig.9), showed a molecular ion peak at $\mathrm{m} / \mathrm{z}=547(2.31 \%)$ corresponding to the cyclopalladate moiety $\left(\mathrm{C}_{18} \mathrm{H}_{16} \mathrm{Cl}_{3} \mathrm{~N}_{4} \mathrm{O}_{3} \mathrm{Pd}\right)$. The base peak was found in the spectrum at $\mathrm{m} / \mathrm{z}=$ $272(100 \%)$ corresponding to the $\left(\mathrm{C}_{15} \mathrm{H}_{13} \mathrm{ClN}_{2} \mathrm{O}\right)$. 


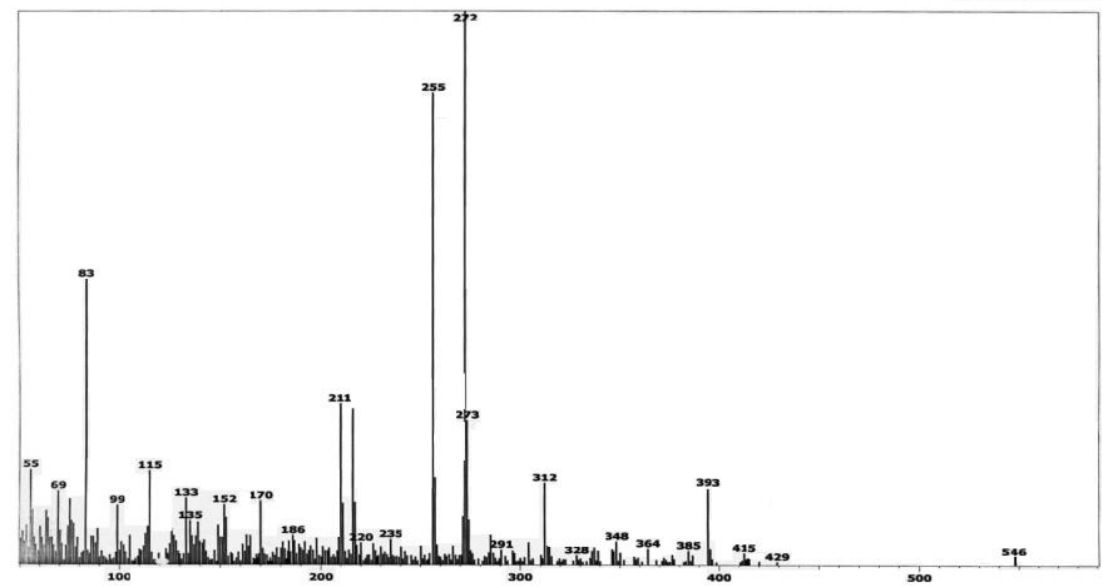

Fig. 9. Mass spectrum of $\left[\mathrm{PdL}_{2} .2 \mathrm{Cl}\right]$ complex.

Thermal analysis of palladium complexes

The majority of compounds including complexes suffer physical and chemical changes when subjected to heat energy. Under defined experimental conditions, these changes are characteristic of such substances and can be used for their qualitative and quantitative analysis. When the sample to be analyzed is heated, various chemical changes (e.g. thermal decom-position, oxidation..., etc) and several physical processes (solvent and water elimination, evaporation, sublimation...,etc) may take place with a consequent change in the weight of the sample. The examination of these processes is the task of thermo gravimetric analysis (TGA) method.

Palladium complexes showed four stages of decomposition. The first weight loss stage in complexes corresponds to the elimination of crystalline water molecules as shown in Fig. 10-12.

The thermal decomposition is finally yielding the corresponding metal oxides, carbides, metallic residue or mixtures.

\section{${ }^{I} H N M R$}

The ${ }^{1} \mathrm{H}$ NMR spectrum (Fig.13) of [PD.L1.2CL]0.5 $\mathrm{H}_{2} \mathrm{O}$ in $\left(\mathrm{CDCl}_{3}\right)$ solvent indicated a signals at $\left.\delta: 0.915-1.22\left(\mathrm{~m}, 8 \mathrm{H},\left[6 \mathrm{H}, 2 \mathrm{CH}_{3}\right)+2 \mathrm{H},\left(\mathrm{CH}_{2}\right)\right]\right), \delta 3.84(\mathrm{~s}, 3 \mathrm{H}$, $\left.\mathrm{OCH}_{3}\right), \delta 7.24-8.03\left(\mathrm{~m}, 6 \mathrm{H}, \mathrm{Ar}-\mathrm{H}\right.$ and $\left.\mathrm{NH}_{2}\right)$.

\section{Elemental analysis}

The elemental analysis shown in Table 2, together with the IR, electronic spectra ,mass spectra, thermal analysis and NMR spectra as well as the palladium content $\operatorname{Pd}\left(\mathrm{L}_{1}\right)$ calc.(21.2), found (20.93), $\mathrm{Pd}\left(\mathrm{L}_{2}\right)$ calc.(20.43), found (20.01)] and $\mathrm{Pd}\left(\mathrm{L}_{3}\right)$ calc. (19.84), found (19.32) suggest that the structures of the palladium complexes are as shown in structures 4-6. 


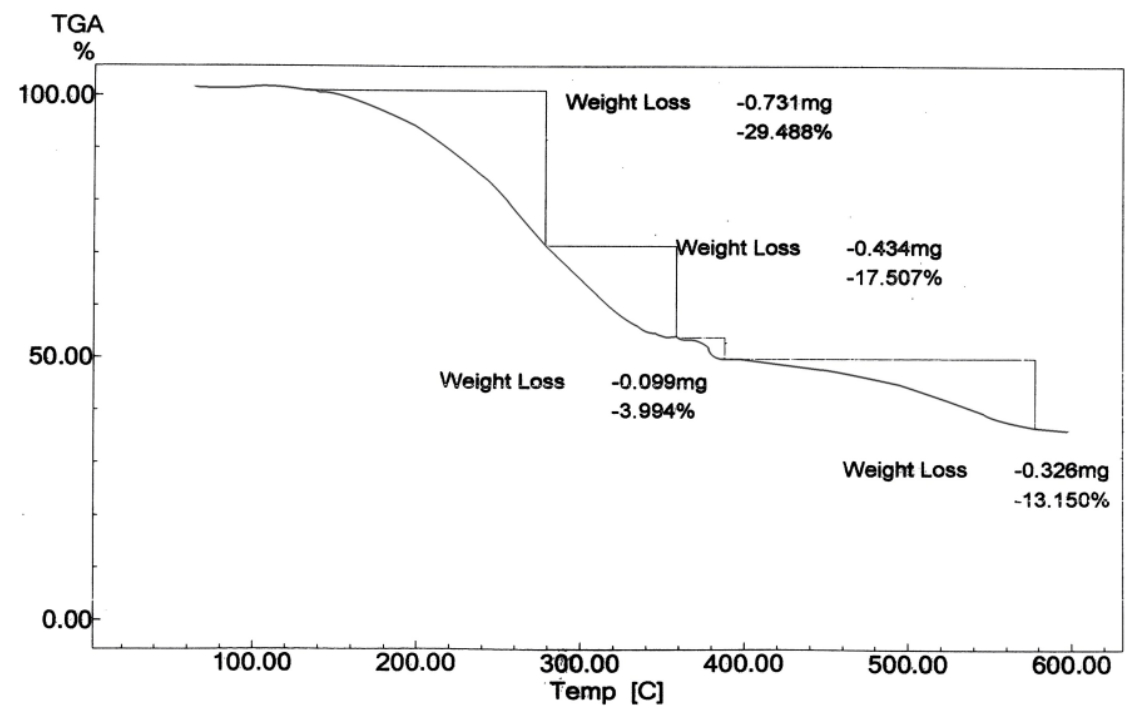

Fig. 10. TGA of the copper complex of $\left[\mathrm{Pd} \mathrm{L}_{1} \cdot 2 \mathrm{Cl}\right] 0.5 \mathrm{H}_{2} \mathrm{O}$.

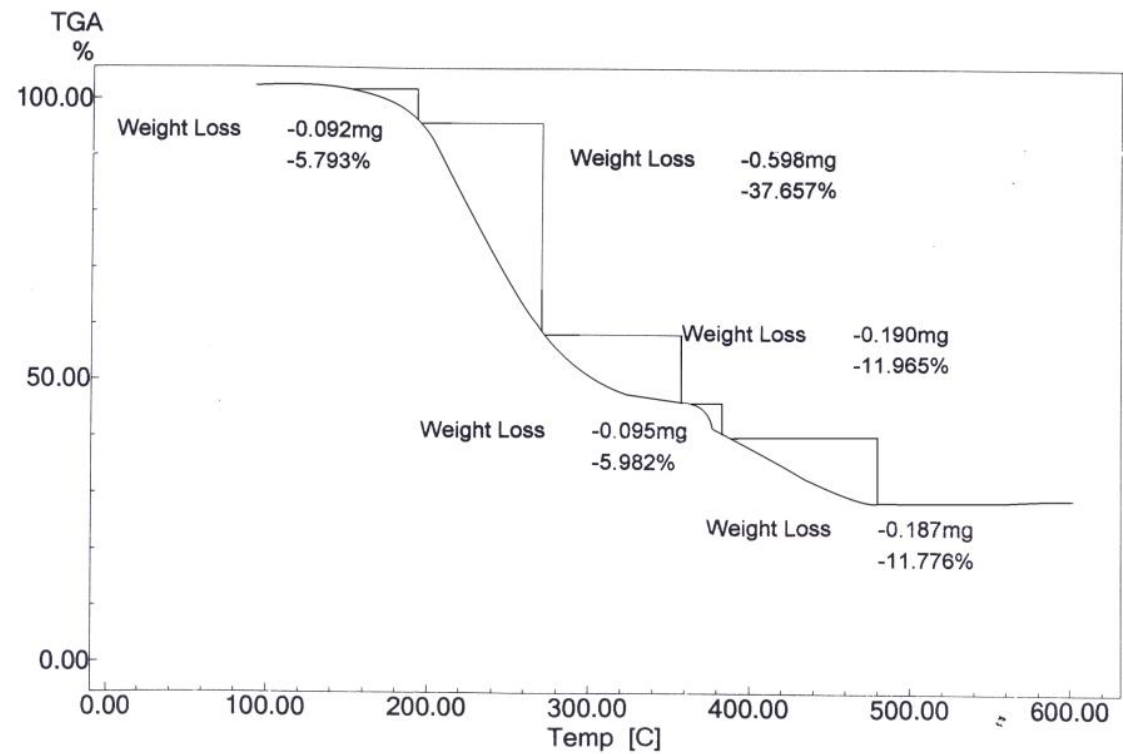

Fig. 11. TGA of the complex of $\left[\mathrm{Pd} \mathrm{L}_{2} .2 \mathrm{Cl}\right] 1.5 \mathrm{H}_{2} \mathrm{O}$.

Egypt. J. Chem. 55, No. 1 (2012) 


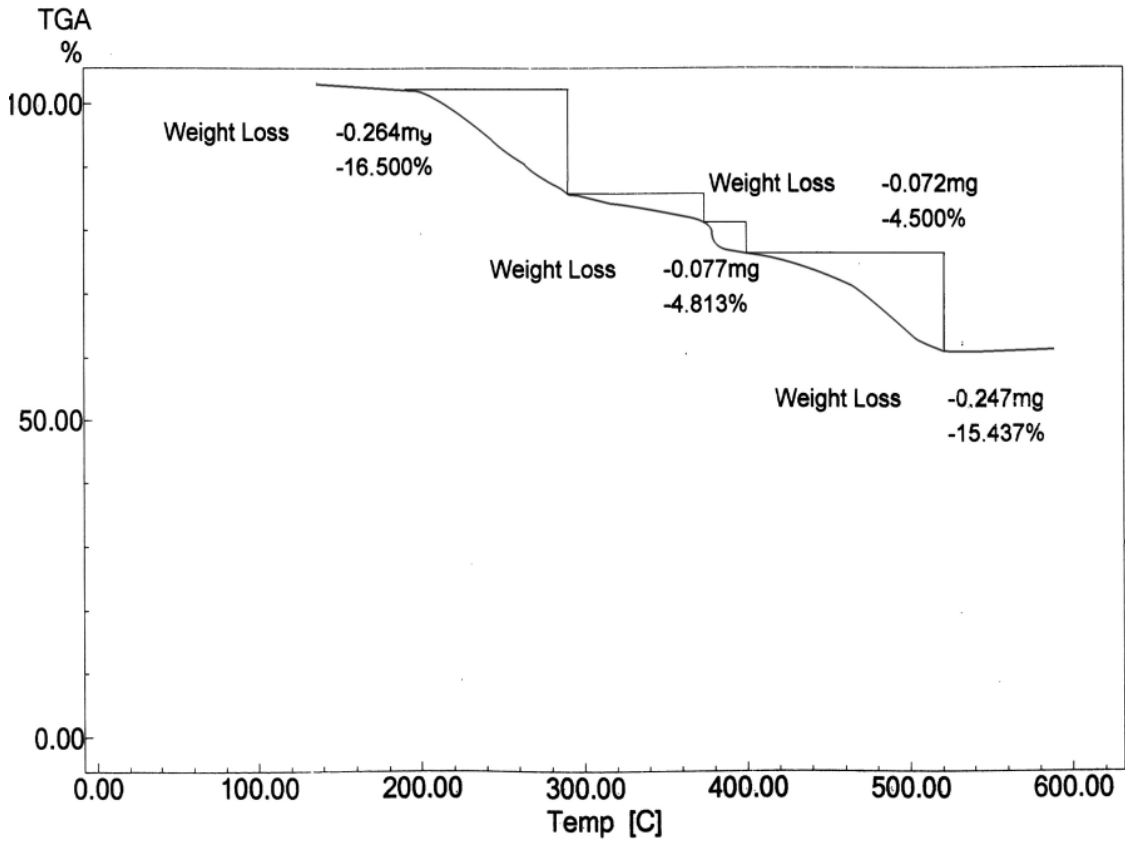

Fig. 12. TGA of the complex of [Pd $\mathrm{L}_{3}$. 2Cl].

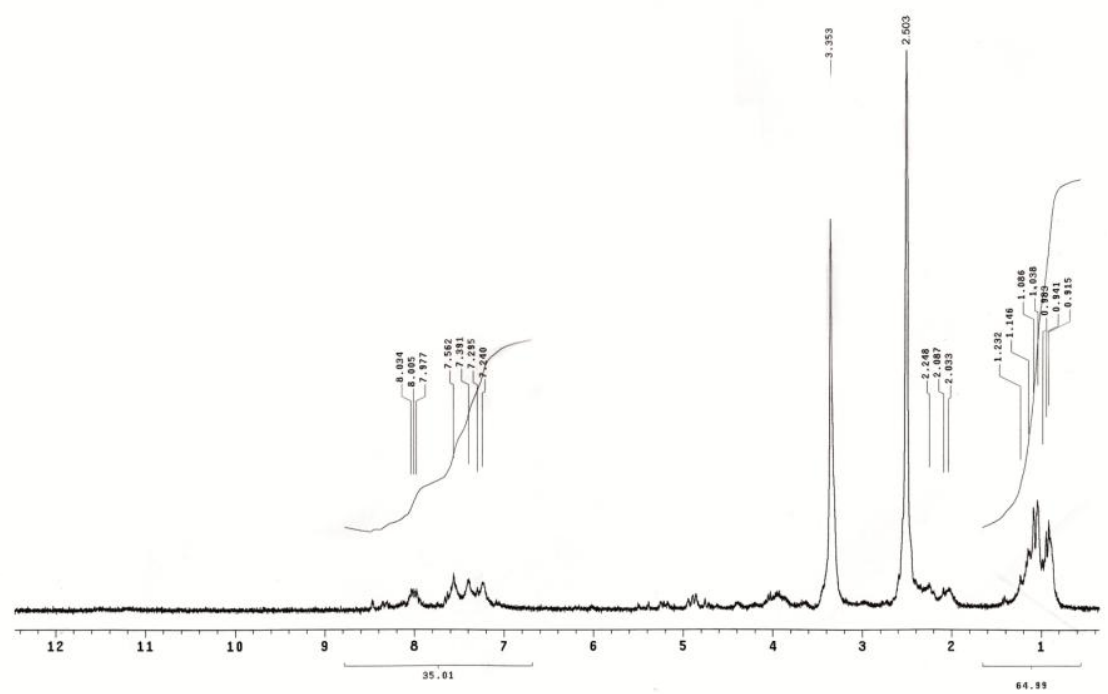

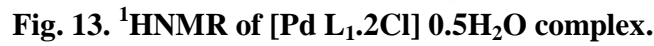

Egypt. J. Chem. 55, No. 1 (2012) 
TABLE 2. Suggestion of the elemental analysis of the Pd complexes .

\begin{tabular}{|c|c|c|c|c|c|c|c|c|c|}
\hline \multirow{2}{*}{$\begin{array}{c}\text { Complex } \\
\text { M.wt }\end{array}$} & \multicolumn{2}{|c|}{$\% \mathrm{C}$} & \multicolumn{2}{|c|}{$\% \mathrm{H}$} & \multicolumn{2}{|c|}{$\% \mathrm{~N}$} & \multicolumn{2}{|c|}{$\%$ Pd } & \multirow{2}{*}{ MP } \\
\hline & Calc & Foud & Calc & Foud & Calc & Foud & Calc & Foud & \\
\hline \multicolumn{10}{|l|}{$\left[\mathrm{Pd} \mathrm{L}{ }_{1}\right]$} \\
\hline 512.5 & 45.31 & 44.49 & 4.86 & 4.32 & 5.46 & 5.13 & 21.2 & 20.93 & 280 \\
\hline \multicolumn{10}{|l|}{$\left[\mathrm{Pd} \mathrm{L} \mathrm{L}_{2}\right]$} \\
\hline 516 & 41.36 & 40.86 & 4.28 & 4.01 & 5.43 & 5.03 & 20.43 & 20.01 & 270 \\
\hline \multicolumn{10}{|l|}{ [Pd L3] } \\
\hline 550 & 39.23 & 39.03 & 2.93 & 2.91 & 7.62 & 9.89 & 19.31 & 19.13 & 290 \\
\hline
\end{tabular}

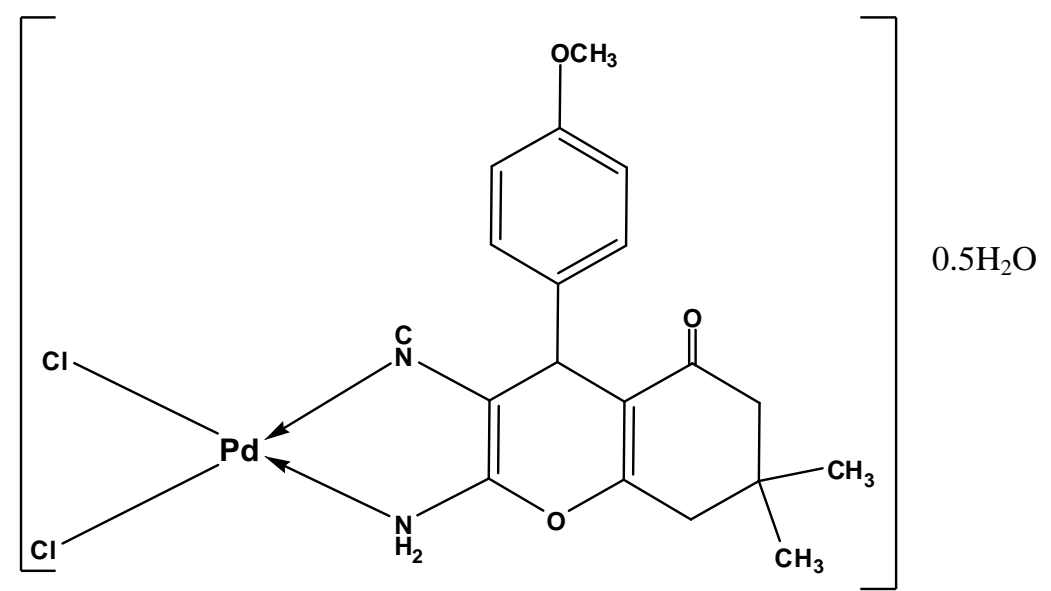

Structure (4) of $\left[\mathrm{Pd} \mathrm{L}_{1}\right]$ complex.

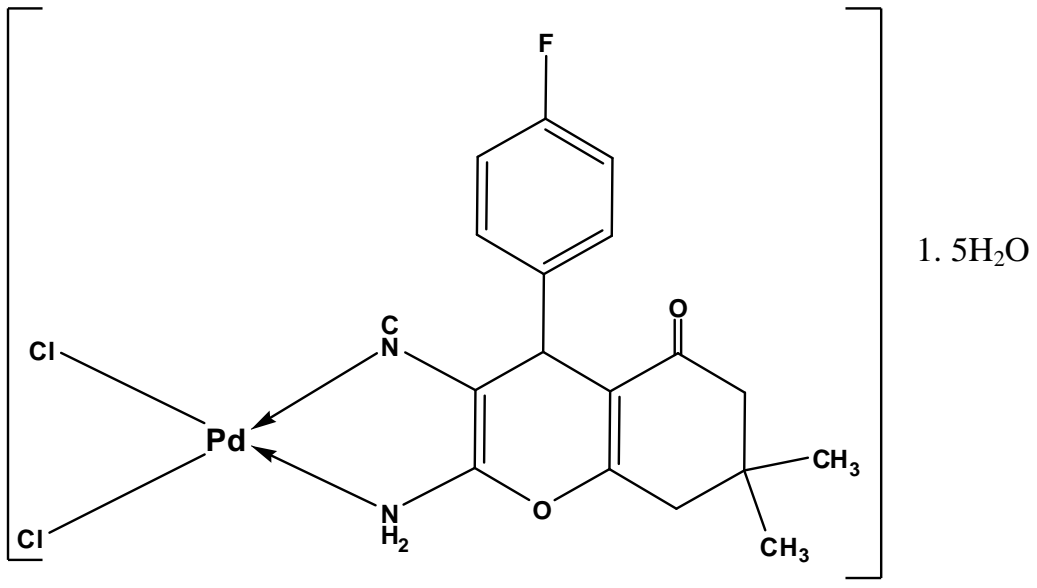

Structure (5) of [Pd $\left.L_{2}\right]$ complex.

Egypt. J. Chem. 55, No. 1 (2012) 


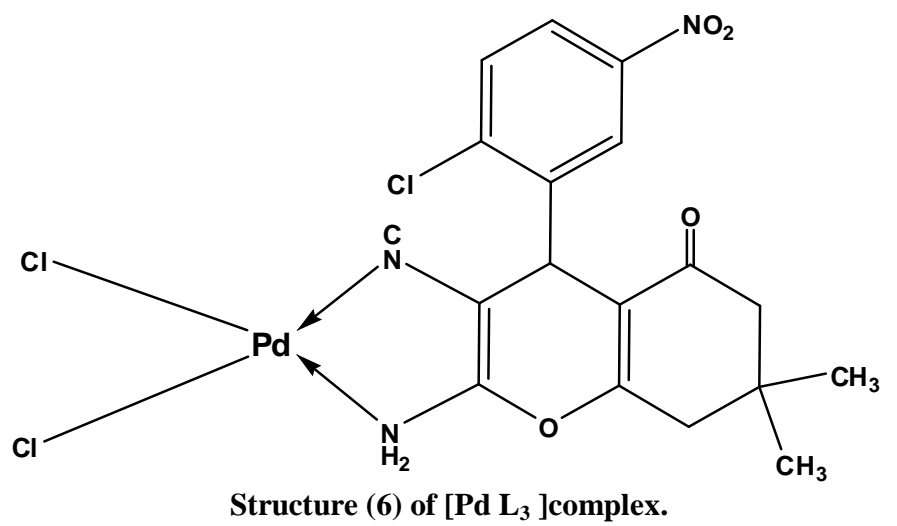

\section{Conclusion}

The well known of benzopyran derivatives have been synthesis by microwave radiation as green chemistry $\left(\mathrm{L}_{1}, \mathrm{~L}_{2}, \mathrm{~L}_{3}\right)$ these ligands have been used to synthesize their palladium (II) complexes This complexes were fully characterized by different tools. The geometry around the palladium ion is found to be square-planar $\left[\mathrm{Pd} \mathrm{L} \mathrm{L}_{1} .2 \mathrm{Cl}\right] 0.5 \mathrm{H}_{2} \mathrm{O},\left[\mathrm{Pd} \mathrm{L}_{2} .2 \mathrm{Cl}\right] 1.5 \mathrm{H}_{2} \mathrm{O}$ and $\left[\mathrm{Pd} \mathrm{L}_{3} .2 \mathrm{Cl}\right]$.

\section{References}

1. Johnson, L. and Killian, C.M., In J. Scheirs, W. Kaminsky, (Ed): Metallocene-Based Polyolefins, Vol. 1, John Wiley \& Sons, Ltd., Chichester (1999).

2. Ittel, S.D., Johnson, L.K. and Brookhart, M., Chem. Rev. J. A. Kanters, J. Organomet. Chem. 358, 545 (1988).100, 1169 (2000).

3. Abu-Surrah, A.S. and Kettunen, M., Curr. Med. Chem. 13, 1337-1357 (2006)

4. (a) Wimmer, F.Z., Wimmer, S., Castan, P., Cros, S., Johnson, N. and ColacioRodrigez, E., Anticancer Res. 9, 791-794 (1989); (b) Zhao, G., Lin, H., Yu, P., Sun, H., Zhu, S., Su, X. and Chen, Y., J. Inorg. Biochem. 73, 145-149 (1999).

5. Abu-Surrah, A.S., Al-Sa'doni, H.H. and Abdalla, M.Y., Cancer Therapy, 6, 1-10 (2008).

6. Mansuri-Torshizi, H., Srivastava, T.S., Parekh, H.K. and Chitnis, M.P., J. Inorg, Biochem. 45, 135-148 (1992).

7. Abu-Surrah, A.S., Al-Allaf, T.A.K., Rashan, L.J., Klinga, M. and Leskela, M., Eur. J. Med. Chem. 37, 919-922 (2002).

8. Ho, Y.P., To, K.K.W., Au-Yeung, S.C.F., Wang, X., Lin, G. and Han, X., J. Med. Chem. 44 2065-2068 (2001).

9. Foye, W.O., Prinicipi di Chemico Farmaceutica; piccin: padova, Italy, 416 (1991) 
10. Bonsi-gnore, L., Loy, G., Secci, D., Secci, and Calignano, A., Eur. J. Med.Chem. 28, 517 (1993).

11. Kumar, D., Reddy, V.B., Sharad, Sh., Dube, U. and Kapur, S., Eur. J. Med. Chem. 44, 3805-3809 (2009).

12. Poyser, H. and Hamilton, T.C., For reviews on potassium channel openers, Potassium channel modulators: current situation and future expectations. Drug of the Future, 19, 39 (1994).

13. Shi, J., Zhuang, Q. and Wang, X., J. Chem. Res. 821 (2004).

14. Fabin, J., Legrand, M. and Poirier, P., Bull. Soc. Chim. France, 1499 (1956).

15. Marco-Contelles, J., Leo', R., 'bal de los Ri'os, C., Garci', A. G., Lo'pez, M. G. and Villarroy, M., Bioorganic \& Medicinal Chemistry, 14, 8176-8185(2006).

16. Ferraro, J.R., Low Frequency Vibration of Inorganic and Coordination Compounds, Plenum, New York (1971).

17. Henning, L., Kirmse, R., Hammerich, O., Larsen, S., Frydendahl, H., Toftlund, H. and Becher, J., Inorg. Chem. Acta, 234, 67. (1995).

18. Schiff, H., Ann. Chem. (Paris) 131, 118 (1964).

(Received $12 / 4 / 2012$

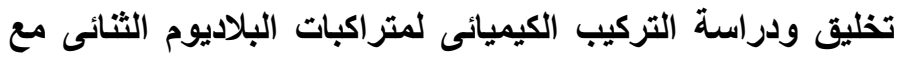

مشتقات البنزوبيران ودانه

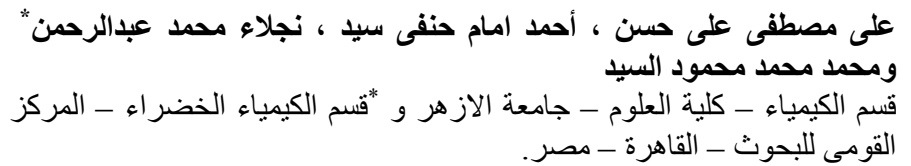

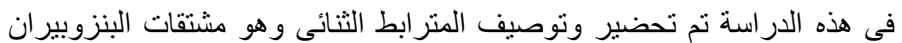

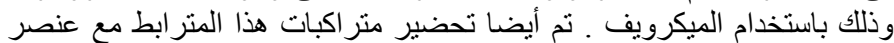

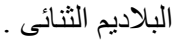

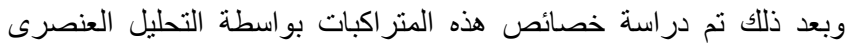

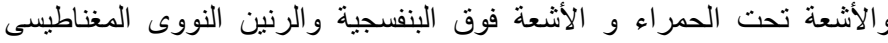

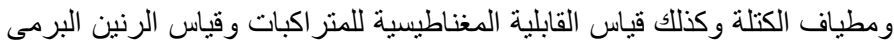

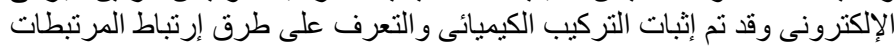

بأيونات العناصر الفلزية.

وبناءا على هذه النتائج وجد أن البنزوبيران يتصرف كمتر ابط ثنائى عند تفاعله

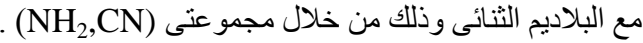

وفى هذه الدر اسة أنبتت القياسات الحر ارية وجود جزيئات الماء داخل وخارج

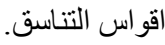

Egypt. J. Chem. 55, No. 1 (2012) 